Feder, N. and T.S. O’Brien. 1968. Plant microtechnique; some principles and new methods. Amer. J. Bot. 55:123-142.

Garr, E. 1965. The rationale use of dyes in biology and general staining methods. Williams \& Wilkins, Baltimore.

Gray, P. 1954. The microtomist's formulary and guide. Blakiston, New York.

Hammerschmidt, R. 1985. Determination of natural and wound-induced potato tuber suberin phenolic acid derivitization and cupric oxide oxidation. Potato Res. 28:123-127.

Johansen, D.A. 1940. Plant microtechnique. McGraw-Hill, New York.

Kolattukudy, P.E. 1984. Biochemistry and function of cutin and suberin. Can. J. Bot. 62:2918-2933.

Kolattukudy, P.E. and V.P. Agrawal. 1974. Structure and composition of aliphatic components of potato tuber skin (suberin). Lipids 9:682-691.

Lauritzen, J.I. 1935. Factors affecting infection and decay of sweet potatoes by certain storage rot fungi. J. Agr. Res. 50:285-329.

O'Brien, T.P., N. Fedder, and M.E. McCully. 1964. Polychromatic staining of plant cell walls by toluidine blue O. Protoplasma 59:368-373.

Rittinger, P.A., A.R. Biggs, and D.R. Pierson. 1987. Histochemistry of lignin and suberin deposition in boundary layers formed after wounding in various plant species and organs. Can. J. Bot. 65:1886-1892.
SAS Institute, Inc. 1985. SAS user's guide: Statistics. Cary, N.C. Schadel, W.E. and W.M. Walter, Jr. 1981. Localization of phenols and polyphenol oxidase in 'Jewel' sweet potatoes (Ipomoea batatas 'Jewel'). Can. J. Bot. 59:1961-1967.

Vance, C.P., T.K. Kirk, and R.T. Sherwood. 1980. Lignification as a mechanism of disease resistance. Annu. Rev. Phytopathol. 18:259288.

Walter, W.M., Jr., and W.E. Schadel. 1982. A rapid method for evaluating curing progress in sweet potatoes. J. Amer. Soc. Hort. Sci. 107:1129-1133.

Walter, W.M., Jr., and W.E. Schadel. 1983. Structure and composition of normal skin and wound tissue from cured sweet potatoes. J. Amer. Soc. Hort. Sci. 108:909-914.

Walton, T.J. and P.E. Kolattukudy. 1972. Determination of the structures of cutin monomers by a novel depolymerization procedure and combined gas chromatography and mass spectrometry. Biochemistry 11:1885-1896.

Weimer, J.L. 1921. Wound cork formation in the sweet potato. J. Agr. Res. 21:637-647.

J. AMER. SOC. Hort. SCI. 115(3):452-454. 1990.

\title{
Chemical Changes in Okra Stored in Air and Controlled Atmosphere
}

\author{
Lawford Baxter ${ }^{1}$ and Luther Waters, Jr. ${ }^{2}$ \\ Department of Horticultural Science and Landscape Architecture, University of Minnesota, \\ St. Paul, MN 55108
}

Additional index words. Abelmoschus esculentus, sugars, organic acids, amino acid, protein, ascorbic acid

\begin{abstract}
Okra (Abelmoschus esculentus L. Moench) pods stored In a controlled atmosphere (CA) of $5 \% \mathrm{O}_{2}$ and $10 \% \mathrm{CO}_{2}$ at $11 \pm 1 \mathrm{C}$ and in air at the same temperature (RA) were compared to determine the effects of the two storage environments on changes in sugars, organic acids, proteins and amino acids, and ascorbic acid contents within the tissue. Pods were sampled at 3-day intervals for 12 days. CA-stored pods generally had greater retention of sugars, soluble proteins, and amino acids than RA-stored pods. Citric, malic, and ascorbic acids contents of CA pods also declined more slowly than those of RA pods.
\end{abstract}

Okra is well-adapted to hot, humid conditions and is a popular vegetable in most tropical countries. Okra not only serves as a thickening agent for soups and stews, but is an important source of nutrients in the diet $(8,9)$. Fresh okra pods have a short postharvest life, being prone to physical and physiological changes that reduce quality (18).

Postharvest treatments such as hydrocooling (6), chemical sprays (11), and modified atmospheres (MA) (1) have been used to extend the postharvest life and maintain the quality of fresh okra. Modified or controlled atmosphere (CA) in conjunction with low temperatures is particularly attractive, since this storage method is generally considered effective in reducing the respiration rates of fresh vegetables and in maintaining quality while leaving no harmful residues. The effects of MA or CA storage on physical and physiological changes in fresh commodities are variable and there are even conflicting reports on the effects of CA storage on a given commodity in some cases

Received for publication 27 June 1988. Paper no. 16,060 of the Scientific Journal Series, Univ. of Minnesota Agricultural Experiment Station. The cost of publishing this paper was defrayed in part by the payment of page charges. Under postal regulations, this paper therefore must be hereby marked advertisement solely to indicate this fact.

${ }_{2}^{1}$ Graduate student.

${ }^{2}$ Associate Professor.
(20). Little work (1) has been done to determine the response of okra fruits to CA storage. The objective of this work was to determine CA effects on changes in the levels of certain chemical compounds in okra.

\section{Materials and Methods}

'Clemson Spineless' okra was grown on the St. Paul campus of the Univ. of Minnesota using standard commercial practice. Pods were harvested 6 days after anthesis, trimmed, immediately forced-air cooled to $\approx 11 \mathrm{C}$ and placed in a $69 \times 37 \times$ $37 \mathrm{~cm}(\mathrm{~L} \times \mathrm{W} \times \mathrm{H})$ plexiglass chamber that then was sealed. A CA consisting of $5 \% \mathrm{O}_{2}, 10 \% \mathrm{CO}_{2}$, and $85 \% \mathrm{~N}_{2}$ (12), prepared by mixing commercially bottled gas from high-pressure cylinders, was passed through an ethylene scrubber into the chamber. A system of flow meters, solenoid valves, and timers controlled the flow of the gas mixture into the chamber and provided for one complete change of the atmosphere about every $16 \mathrm{hr}$. Temperature and relative humidity were maintained at $11 \pm 1 \mathrm{C}$ and $90 \%$ to $95 \%$, respectively. Control pods were stored at the same temperature and relative humidity in air (RA). Air flow rate in the control chamber was the same as that of the CA chamber. Each test consisted of a single treatment and control chamber with three tests per year for 2 years.

Pods were removed from storage at 3-day intervals for 12 days, freeze-dried, and ground to a fine powder in a cyclone 
sample mill (UD Corp., Boulder, Colo.). This powder was used for all chemical measurements. Total ascorbic acid content was determined by extracting $0.5 \mathrm{~g}$ of the freeze-dried material with $10 \mathrm{ml}$ of a $1: 1$ mixture (v/v) of $1 \mathrm{~N}$ sulfuric and $2 \%$ metaphosphoric acids. The mucilage was precipitated with $5 \mathrm{ml}$ of $80 \%$ ethanol and the extract centrifuged at $10,000 \times g$ for $30 \mathrm{~min}$. The supernatant was poured off and aliquots used for ascorbic acid analysis by a spectrophotometric method using indophenol dye (15). For sugar determination, $50 \mathrm{mg}$ of the freeze-dried powder were extracted with $5 \mathrm{ml}$ of deionized water at 60 to $65 \mathrm{C}$ for $2 \mathrm{hr}$ followed by centrifugation at $1500 \times \mathrm{g}$ for $30 \mathrm{~min}$. The supernatant was filtered through a C-18 Sep-Pak preparatory column (Waters Assoc., Milford, Mass.) and evaporated to dryness. The residue was resuspended in $0.5 \mathrm{ml}$ of deionized water followed by the addition of $1.5 \mathrm{ml}$ of acetonitrile. The sample was passed through a $0.5-\mu \mathrm{m}$ filter and injected into a Waters WISP 710B HPLC system fitted with a refractive index detector and a $3.9 \times 300 \mathrm{~mm}$ carbohydrate analysis column. The mobile phase was $85 \%$ acetonitrile (v/v) at a flow rate of $2 \mathrm{ml} \cdot \mathrm{min}^{-1}$. Fructose, glucose, and sucrose were quantified using an external standard of $1 \mathrm{mg}$ of each sugar/ml. Malic and citric acid contents were analyzed using enzyme kits (3). For amino acid analysis, $0.5 \mathrm{~g}$ of the material was extracted with $10 \mathrm{ml}$ of $80 \%$ ethanol followed by centrifugation at $10,000 \times$ $g$ for $30 \mathrm{~min}$. The supernatant was collected and aliquots were used for amino acid analysis using ninhydrin (21). The pellet remaining after centrifugation was extracted with $0.1 \mathrm{~N} \mathrm{NaOH}$ and centrifuged at $10,000 \times g$ for $30 \mathrm{~min}$. The supernatant was collected and aliquots were used to determine soluble protein content using Coomassie brilliant blue (4). Total $\mathrm{N}$ was determined on $100 \mathrm{mg}$ of the freeze-dried powder using the Kjeldahl method (2) and crude protein calculated as $\%{ }^{`} \mathrm{~N} \times 6.25$.

The experimental design was a randomized complete block (RCB) with three replications. Each replication consisted of $\approx 1360 \mathrm{~g}$ of uniformly sized fruits. The experiment was conducted during the 1986 and 1987 growing seasons. Because little difference was observed between the data from both years, the data for each compound were combined. The appropriate statistical analysis for an RCB design was performed on the data at each sampling. All values represent the means of six observations.

\section{Results and Discussion}

CA-stored pods had good color and appearance and still were potentially salable after 12 days compared to RA pods, which had begun to decay and were of poor quality (data not shown). Significant changes in the levels of primary metabolites occurred for both RA- and CA-stored okra. There was a loss of sugars under both storage conditions (Table 1), but the loss generally was greater in RA than CA pods. This is consistent with results for tomatoes (17) and lettuce (19). At the end of storage, total sugars had declined by $37 \%$ in RA-stored pods, compared to $2 \%$ for CA pods. The storage environment did not affect the three sugars in the same manner. For CA pods, the fructose content showed a consistent increase after day 3, but there was a steady decline in both the glucose and the sucrose content. All three sugars declined in RA pods, with fructose showing the greatest loss (Table 1). The slower rate of sugar loss seen in CA pods may be due to inhibition of respiration possibly by inhibition of glycolysis (13) or postglycolytic processes (14). The accumulation of fructose in CA pods (Table 1) indicates an impairment of glycolysis, possibly after fructose biosynthesis. Organic acid analysis showed higher citrate and malate levels in CA pods (Fig. $1 \mathrm{~A}$ and B), supporting the theory that postglycolytic reactions in okra may be influenced by CA.

Both CA and RA pods lost ascorbic acid during storage (Fig. 2 ), but the loss was slightly greater for RA pods than those stored in CA. In general, ascorbic acid retention in fresh vegetables is enhanced by CA (7). The effects of CA on ascorbic acid content in fresh vegetables varies, depending on atmosphere composition, temperature, duration of storage, and type of commodity. Conditions that maintain tissue integrity are thought to prevent ascorbic acid degradation in perishable commodities (5). In the present study, CA pods, which were more turgid and had better color and appearance than the controls (data not shown), lost less ascorbic acid. By day 8 of storage, RA pods had visible symptoms of Alternaria rot and, by the end of the study, there was advanced decay with oozing of a slimy substance.

There was little change in crude protein content over the storage period (range 13-16 g/100 g), but CA pods retained more soluble proteins than RA pods (Table 1). At the end of storage, soluble protein content had declined by $17.6 \%$ in CA pods compared to $49 \%$ in RA pods. Similar losses in protein content after harvest have been reported for asparagus (16). Protein loss could be due to respiratory activity to provide carbons for Krebs cycle reactions (10).

A decline in the free amino acid content of CA pods during storage was noted in comparison to an increase for RA pods (Table 1). At the end of storage, free amino acids had declined by $\approx 43 \%$ in CA pods, compared to an increase of $\approx 24 \%$ for RA pods. Loss of free amino acids in CA-stored okra may represent free amino acids being used for protein synthesis or possible respiration. Conversely, protein hydrolysis could account for the increase in free amino acid concentration in RA pods. The protein and amino acids in fresh fruits and vegetables are in a constant state of flux, with proteins being hydrolyzed to their component amino acids and amino acids going to protein

Table 1. Sugar, soluble protein, and free amino acids content (dry-weight bases) of okra pods stored in $5 \% \mathrm{O}_{2}+10 \% \mathrm{CO}_{2}(\mathrm{CA})$ and air (RA). ${ }^{\mathrm{Z}}$

\begin{tabular}{|c|c|c|c|c|c|c|c|c|c|c|}
\hline \multirow{2}{*}{$\begin{array}{l}\text { Days in } \\
\text { storage }\end{array}$} & \multicolumn{2}{|c|}{$\begin{array}{l}\text { Fructose } \\
\left(\mu g \cdot g^{-1}\right)\end{array}$} & \multicolumn{2}{|c|}{$\begin{array}{l}\text { Glucose } \\
\left(\mu g \cdot g^{-1}\right)\end{array}$} & \multicolumn{2}{|c|}{$\begin{array}{c}\text { Sucrose } \\
\left(\mu g \cdot g^{-1}\right)\end{array}$} & \multicolumn{2}{|c|}{$\begin{array}{c}\text { Soluble } \\
\text { protein } \\
\left(\mathrm{mg} \cdot \mathrm{g}^{-1}\right)\end{array}$} & \multicolumn{2}{|c|}{$\begin{array}{c}\text { Free amino } \\
\left(\mathrm{mg} \cdot \mathrm{g}^{-1}\right)\end{array}$} \\
\hline & RA & $\mathbf{C A}$ & $\mathbf{R A}$ & CA & RA & $\mathrm{CA}$ & $\mathrm{RA}$ & $\mathrm{CA}$ & $\mathrm{RA}$ & $\mathrm{CA}$ \\
\hline $\begin{array}{r}0 \\
3 \\
6 \\
9 \\
12\end{array}$ & $\begin{array}{l}40 \mathrm{a} \\
37 \mathrm{a} \\
35 \mathrm{a} \\
29 \mathrm{a} \\
24 \mathrm{a}\end{array}$ & $\begin{array}{l}40 a \\
38 a \\
41 b \\
47 b \\
59 b\end{array}$ & $\begin{array}{l}39 a \\
37 a \\
32 a \\
27 a \\
25 a\end{array}$ & $\begin{array}{l}39 \mathrm{a} \\
36 \mathrm{a} \\
35 \mathrm{a} \\
31 \mathrm{~b} \\
33 \mathrm{~b}\end{array}$ & $\begin{array}{l}32 \mathrm{a} \\
26 \mathrm{a} \\
25 \mathrm{a} \\
22 \mathrm{a} \\
21 \mathrm{a}\end{array}$ & $\begin{array}{l}32 \mathrm{a} \\
29 \mathrm{a} \\
27 \mathrm{a} \\
26 \mathrm{~b} \\
11 \mathrm{~b}\end{array}$ & $\begin{array}{l}77.2 \mathrm{a} \\
57.4 \mathrm{a} \\
48.6 \mathrm{a} \\
44.2 \mathrm{a} \\
39.4 \mathrm{a}\end{array}$ & $\begin{array}{l}77.2 \mathrm{a} \\
69.0 \mathrm{~b} \\
64.2 \mathrm{~b} \\
58.0 \mathrm{~b} \\
63.6 \mathrm{~b}\end{array}$ & $\begin{array}{l}59.2 \mathrm{a} \\
61.0 \mathrm{a} \\
63.2 \mathrm{a} \\
69.0 \mathrm{a} \\
73.3 \mathrm{a}\end{array}$ & $\begin{array}{l}59.3 \mathrm{a} \\
59.1 \mathrm{a} \\
47.7 \mathrm{~b} \\
40.5 \mathrm{~b} \\
34.0 \mathrm{~b}\end{array}$ \\
\hline
\end{tabular}

${ }^{\mathrm{z}}$ Mean separation between columns within a category at each sampling date by $\mathrm{F}$ test, $P<$ 0.05 . Means of six observations. 


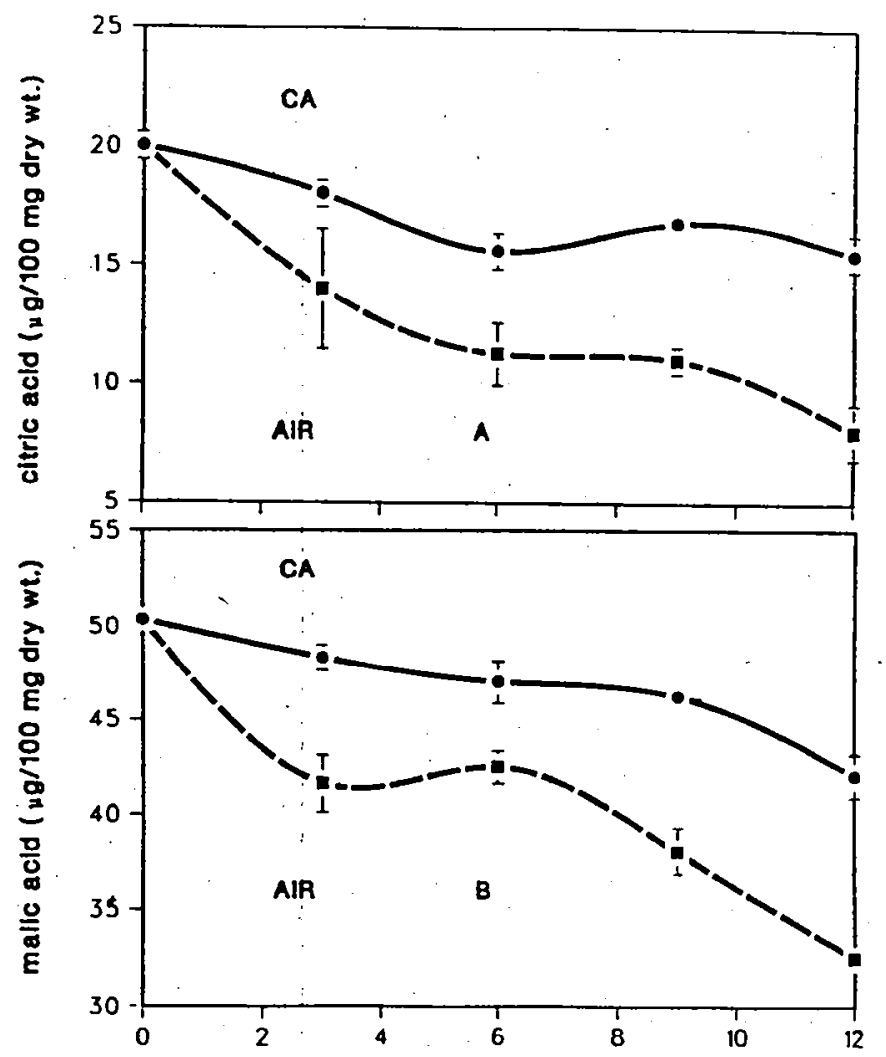

Fig. 1. Changes in citric acid (A) and malic acid (B) of okra pods stored in $5 \% \mathrm{O}_{2}+10 \% \mathrm{CO}_{2}$ or air. Data points represent the means of six observations. Vertical bars represent \pm SE. Bars not shown when smaller than point markets.

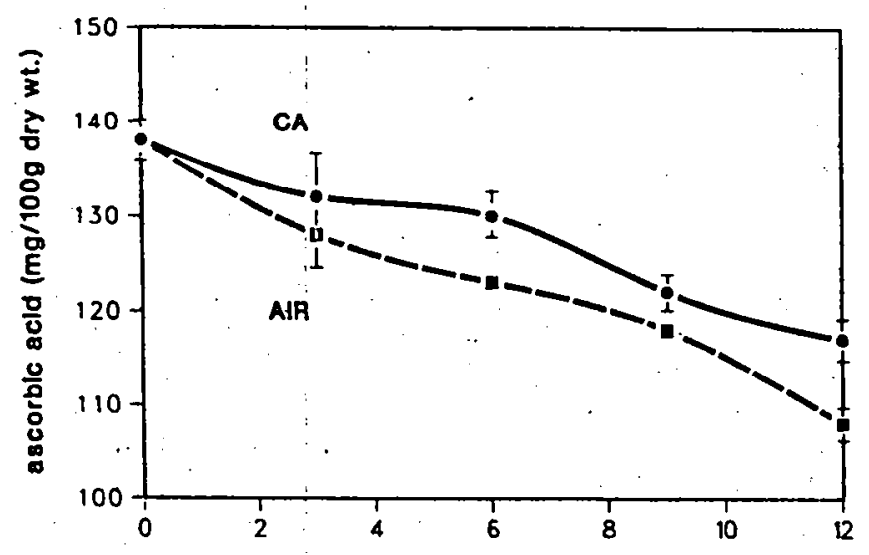

Fig. 2: Changes in ascorbic acid content of okra pods stored in 5\% $\mathrm{O}_{2}+10 \% \mathrm{CO}_{2}$ or air. Data points represent the means of six observations. Vertical bars represent \pm SE. Bats not shown when smaller than point markers.

synthesis. This will ultimately affect the net content of these metabolites in harvested plant tissues.

\section{Literature Cited}

1. Anandaswamy, B. 1963. Prepackaging studies on fresh produce. IV. 0 kra (Hibiscus esculentus). Food Sci. (Mysore) 12:332-335.

2. Association of Official Analytical Chemists. 1975. Official methods of analysis. 12 ed. AOAC, Washington, D.C.

3. Boerhinger Mannheim Biochemicals. 1985. Methods of biochemical analysis and food analysis. Boehringer Mannheim Biochemicals, Indianapolis.

4. Bradford, M. 1976. A rapid and sensitive method for the quantitation of microgram quantities of protein utilizing the principles of protein-dye binding. Anal. Biochem. 72:248-254.

5. Ezell, B.D. and M.S. Wilcox. 1959. Loss of vitamin C in fresh vegetables as related to wilting and temperature. Agr. Food Chem. 7:507-509.

6. Fontenot, J.F., P.W. Wilson, K. Butts, D.M. Shuh, and H.M. Brewer. 1987. Extending the shelf life of okra pods. Louisiana Agr. 30:16-18.

7. Heinze, P.H. 1974. The influence of storage, transportation and market conditions on composition and nutritional value of fruits and vegetables, p. 133-145. In: P.L. White and N. Selvey (eds.). Nutritional qualities of fresh fruit and vegetables. Futura Publishing Co., Mount Kisko, N.Y.

8. Ifon, E.T. and O. Bassir. 1979. The nutritive value of some Nigerian leafy green vegetables. Part 1. Vitamin and mineral content. Food Chem. 4:263-267.

9. Ifon, E.T. and O. Bassir. 1980. The nutritive value of some Nigerian leafy green vegetables. Part 2. The distribution of protein, carbohydrate (including ethanol soluble simple sugars), crude fat, fibre and ash. Food Chem. 5:231-235.

10. James, W.O. 1953. Plant respiration. Oxford Univ. Press, London.

11. Joshi, H.C., N. Joshi, N.C. Joshi, and P.C. Pant. 1984. Storage life of okra. Sci. \& Cult. 50:90-91.

12. Kader, A.A.., R.F. Kasmire, F.G. Mitchell, M.S. Reid, N.F. Sommer, and J.F. Thompson. 1985. Postharvest technology of horticultural crops. Univ. of California Special Publ. 3311. p. 60.

13. Kerbel, L.X., A.A. Kader, and R.J. Romani. 1987. Mode of carbon dioxide action on glycolysis in 'Bartlett' pears fruit. HortScience 22:152. (Abstr.)

14. Preiss, J. and T. Kosuge. 1976. Regulation of enzyme activity in metabolic pathways, p. 278-336. In: J. Bonner and J.E. Varner (eds.). Plant biochemistry. Academic, New York.

15. Ruck, J.A. 1963. Chemical methods for analysis of fruit and vegetable products. Can. Dept. Agr. Publ. 1154.

16. Saltveit, M.E. and R.F. Kasmire. 1985. Changes in respiration and composition of different length of asparagus spears during storage. HortScience 20:1114-1116.

17. Salunkhe, D.K. and M.T. Wu. 1973. Effects of low oxygen atmospheres storage on ripening and associated biochemical changes of tomato fruits. J. Amer. Soc. Hort. Sci. 98:12-14.

18. Singh, B.P., D.K. Bhatnagar, and O.P. Gupta. 1978. Effect of growth retardants and wax emulsion on the shelf life of okra (Abelmoschus esculentus L.). Haryana J. Hort. Sci. 7:91-94.

19. Singh, B., D.J. Yang, and D.K. Salunkhe. 1972. Controlled atmosphere storage of lettuce. 2. Effects on biochemical composition of the leaves. J. Food Sci: 37:52-55.

20. Weichmann, J. 1986. The effect of controlled-atmosphere storage on the sensory and nutritional quality of fruits and vegetables. Hort. Rev. 8:101-127.

21. Yemm, E.Y. and E.C. Cocking. 1955. The determination of amino acids with ninhydrin. Analyst 80:209-213. 